\title{
Origin and Evolution of Gas in Salt Beds of a Potash Mine
}

\author{
Martin Zimmer $^{1}$, Bettina Strauch ${ }^{1}$, Axel Zirkler ${ }^{2}$, Samuel Niedermann $^{1}$, and Andrea Vieth-Hillebrand ${ }^{1}$ \\ ${ }^{1}$ Helmholtz Centre Potsdam, GFZ German Research Centre for Geosciences, Potsdam, Germany \\ ${ }^{2} \mathrm{~K}+\mathrm{S}$ Aktiengesellschaft, Kassel, Germany
}

Correspondence: Martin Zimmer (weihei@gfz-potsdam.de)

Received: 10 June 2020 - Revised: 23 July 2020 - Accepted: 31 July 2020 - Published: 22 September 2020

\begin{abstract}
In order to better understand both the fixation and migration of gases in evaporites, investigations were performed in five horizontal boreholes drilled in an underground potash seam. One of the five boreholes was pressurised with $\mathrm{Ar}$ and the pressure signal and chemical gas composition were then monitored in the other holes. A further gas sample from a separate borehole was characterised for the chemical composition and for noble gas and carbon isotopic compositions to conclude on the origin and evolution of the gas in the salt rocks. Additionally, in order to determine the total gas amount in the salt rocks, a potash-bearing salt sample was dissolved in water and from the mass of $1 \mathrm{~kg}$ salt sample, $9 \mathrm{~cm}_{\text {(STP) }}^{3}$ gas was liberated. Due to the relatively large permeability of the disturbed salt rocks $\left(4 \times 10^{-17}\right.$ to $4 \times 10^{-18} \mathrm{~m}^{2}$ ), which is about 3-4 orders of magnitude higher than in undisturbed salt rocks, we assume that the migration of injected Ar most likely takes place along micro-cracks produced during the mining process. The geogenic gas concentrations found in the observation holes correlate directly to the Ar concentration, suggesting that they were stripped from the rocks in between the holes. According to the Heisotopes $(0.092 \mathrm{Ra})$, a small contribution of mantle gas can be found in the geogenic salt gas. The $\delta^{13} \mathrm{C}_{\mathrm{CO}_{2}}$-isotopic composition $(-7.8 \%$ to $6.7 \%$ o $)$ indicates a magmatic source, whereas ${ }^{13} \mathrm{C} /{ }^{12} \mathrm{C}$ of $\mathrm{CH}_{4}(-22.2 \%$ o to $-21.3 \%$ ) is typical for a thermogenic gas. We assume that $\mathrm{CO}_{2}$ and $\mathrm{CH}_{4}$ are related to volcanic activity, where they isotopically equilibrated at temperatures of 513 to $519^{\circ} \mathrm{C}$ about $15-16 \mathrm{Ma}$ ago.
\end{abstract}

\section{Introduction}

Salt deposits contain liquids and gases of varying composition and concentration. The gases present in salts are mainly mixtures of different components with regionally differing compositions and quantities. In the North-German Basin, gases consist mainly of hydrocarbons and $\mathrm{N}_{2}$ with lower concentrations of $\mathrm{CO}_{2}$, whereas in the Werra-Fulda deposits $\mathrm{CO}_{2}$ is the dominant gas (Müller, 1958). Here, the $\mathrm{CO}_{2}$ originates from the Oligocene and Miocene basaltic volcanism, where large amounts of hot $\mathrm{CO}_{2}$-bearing fluids reached the Zechstein evaporites (Knipping, 1989). In the WerraFulda deposits, over $90 \%$ of these gases are bound at the grain boundaries along inter-crystalline fissures and fractures as free gas (Hofrichter, 1976). Sometimes pressurized gases are entrapped in cavernous structures, comprising up to $10000 \mathrm{~m}^{3}$ (Junghans, 1955). During the mining process, these caverns can explosively liberate gas which is a significant threat for miners. Therefore, the encountered gases bound in the evaporites must be monitored carefully. In this article we present results of gas measurements performed in an underground mine of the Werra-Fulda potassium area in Germany. The aim of the study is to better understand the fixation and the migration of gases in evaporites and to make statements on the amount, the origin and the evolution of gas in salt beds of a potash mine.

\section{Geological context}

In eastern Hesse and western Thuringia, Germany hosts significant potassium-bearing salt deposits industrially excavated in the Werra-Fulda mining district. The salt belongs to the upper Permian (Zechstein) and was deposited around 258-252.5 Ma ago. In the Werra-Fulda mining district, the halite rocks (Werra-Rocksalt, z1NA) have a thickness of up 
to $300 \mathrm{~m}$ and contain two minable potash seams, potash Seam Thüringen (z1KTh) and potash Seam Hessen (z1KHe), with an average thickness between 2 and $3 \mathrm{~m}$. In the vicinity of the potash deposits, magmatic rocks of the Vogelsberg and Rhön area are found. Magmatic activity in the Vogelsberg region occurred between ca. 18 and 15.5 Ma (Nesbor, 2018), whereas published age data of the Rhön area show a wider spread between late Oligocene and Miocene ages (Abratis et al., 2007; Knipping, 1989). The occurrence of basaltic dykes within the salt deposit is known since the beginning of mining activities (Dietz, 1928). The dykes dominantly trend in a north-south direction with near vertical inclination (Knipping, 1989). Associated with the volcanic activity, $\mathrm{CO}_{2}$-accumulations can be trapped leading to the formation of gas-bearing salt rocks.

\section{Methods and sampling locations}

For determination of the gas composition in salt, different methods were used both in the laboratory and in the field.

In the laboratory, the total gas amount in potassiumbearing salt (hardsalt) was determined by dissolving a sample taken from Seam Hessen in demineralized water. About $150 \mathrm{~g}$ of the salt sample were placed in a degassing vessel set in an ultrasonic bath. The degassing container was filled with $800 \mathrm{~mL}$ of degassed water to dissolve the salt. To reach complete gas liberation, the ultrasonic treatment was started. Due to the ultrasonic agitation, the gas accumulated quantitatively in the head space. The pressure increase in the head space was monitored continuously and the volume of the head space was determined at the end of the dissolution process.

The migration behavior of gas in the evaporites was studied in situ in five horizontal boreholes drilled in Seam Hessen (Fig. 1). The test site was located in a salt pillar $(20 \mathrm{~m} \times 20 \mathrm{~m})$, excavated in the common room-and-pillar mining method by drilling and blasting. The holes ( $\varnothing 49 \mathrm{~mm}$, depth $2 \mathrm{~m}$ ) were drilled in a dry drilling procedure. The deepest $50 \mathrm{~cm}$ of the holes were closed with a mechanical packer system (Fa. Comdrill). These isolated borehole sections were connected to $6 \mathrm{~mm}$ stainless steel tubing fed through the packers and closed with needle valves (FITOK GmbH). The distance between the boreholes ranges between 0.25 and $2.7 \mathrm{~m}$. At the beginning of a sampling campaign, all boreholes were evacuated to about $3 \mathrm{kPa}$ using a vacuum pump (N813.4 ANE, KNF Neuberger GmbH). Borehole D4 was then immediately filled with pure Ar to a pressure of $0.2 \mathrm{MPa}$. After about 4 weeks, the borehole gases were collected in gas bags with the vacuum pump and the holes were evacuated again to about $3 \mathrm{kPa}$. This procedure was repeated 6 times, approximately every 4 weeks. For the complete time period the pressure course in all boreholes was monitored continuously.

A further gas sample was collected from a separate borehole (bh-1) before the Ar injection was started. First, the

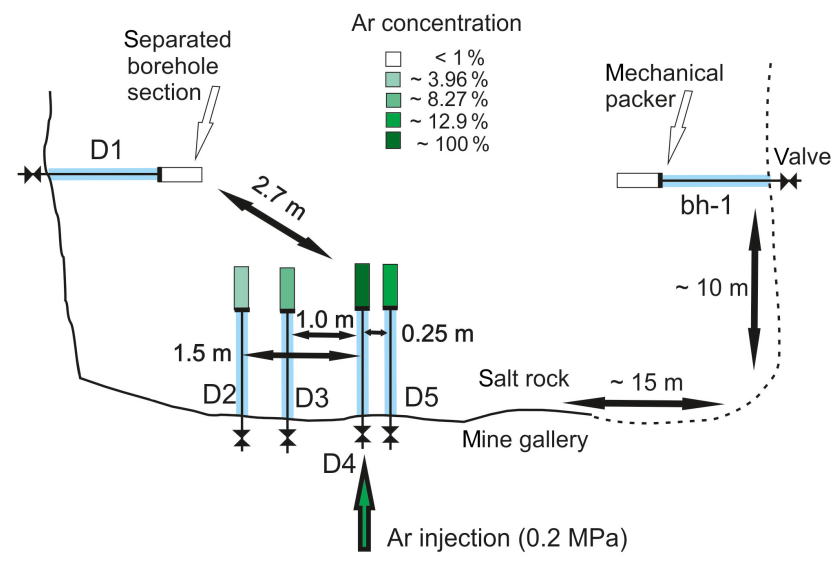

Figure 1. Plane view of the boreholes D1 to D5 in Seam Hessen (z1KHe) with average Ar concentrations and distance to the injection hole as well as the isolated pristine borehole bh-1 (dimensions are not in true scale).

packered section of bh-1 was evacuated with a vacuum pump and a gas sample was collected four weeks later, which potentially allowed gas migration from the salt pillar to the borehole. This gas sample, which was not influenced by the Ar injection, was analysed for its chemical, noble gas and carbon isotopic composition.

The chemical composition of the gas sample was analysed using an Omnistar (Pfeiffer Vacuum) quadrupole mass spectrometer with closed ion source and a mass range of 1-100 atomic mass units. Additionally, a fraction of the same sample was analysed with a gas chromatograph (SRI $8600 \mathrm{C}$ ) equipped with a mol-sieve column and a HI-detector as well as a silica gel column with a TC-detector. Calibration was performed with certified test gases, the relative standard deviation of the gas components $\mathrm{Ar}, \mathrm{He}, \mathrm{CO}_{2}, \mathrm{CH}_{4}$ and $\mathrm{H}_{2}$ was $10 \%$.

Appropriate sample splits were analysed for noble gas concentrations and isotopic compositions with a VG 5400 noble gas mass spectrometer after removing the active gas components in a preparation line for gas purification.

Carbon isotope composition of $\mathrm{CH}_{4}$ and $\mathrm{CO}_{2}$ were analysed by GC-IRMS, consisting of a gas chromatograph (GC 6890N, Agilent Technology) connected to a GC-C/TC III combustion device coupled via open split to a MAT 253 mass spectrometer (Thermo Fisher). The $\delta^{13} \mathrm{C}$ values were reported in $\% \circ$ vs. VPDB with a standard deviation of $\pm 0.5 \%$.

\section{Results and discussion}

\subsection{Total gas amount in Seam Hessen}

The total volume of liberated gas at standard temperature and pressure $\left(V_{\text {gas (STP) }}\right)$ from the salt sample of Seam Hessen was calculated using Eq. (1), based on the volume of the head space ( $\left.V_{\text {headspace }}\right)$, the temperature in Kelvin $(T)$, and 


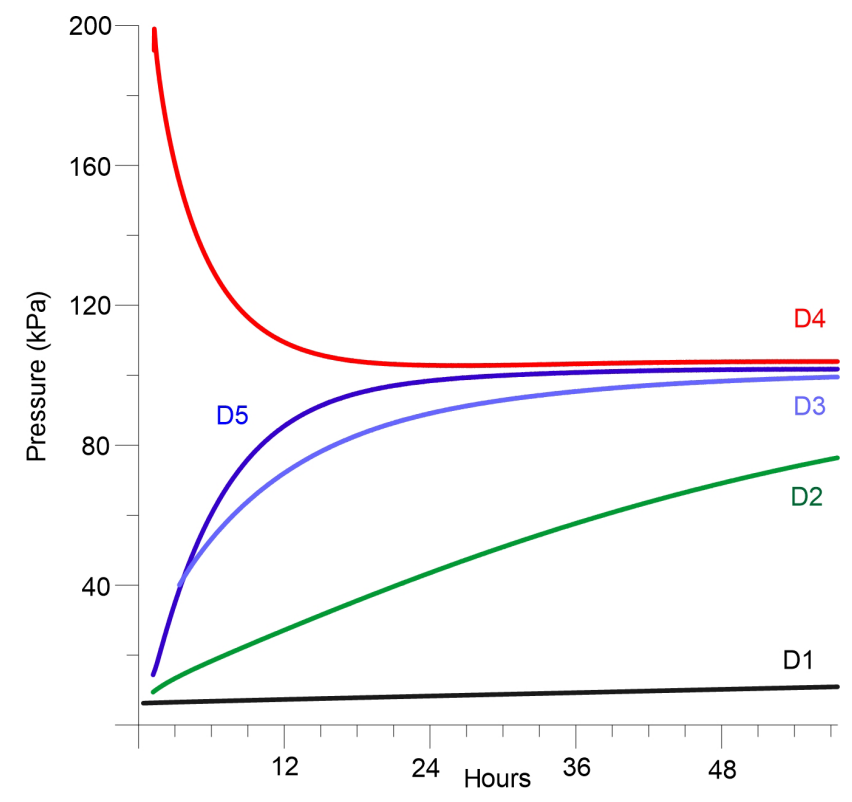

Figure 2. Pressure over time in the boreholes D1 to D5 of the test pillar.

the measured pressure increase $(\Delta P)$ in the reaction-vessel:

$$
V_{\text {gas }(\mathrm{STP})}=\frac{V_{\text {headspace }} \times \Delta P}{101.3} \times \frac{273.15}{T}\left[\frac{\mathrm{cm}^{3} \mathrm{kPa}}{\mathrm{kPa}} \frac{\mathrm{K}}{\mathrm{K}}\right]
$$

From the mass of $1 \mathrm{~kg}$ salt sample, $9 \mathrm{~cm}_{(\text {STP })}^{3}$ of gas was liberated. This value is in the range of values given for hard salt and carnallite with $10 \mathrm{~cm}_{\mathrm{STP}}^{3}$ and $5 \mathrm{~cm}_{\mathrm{STP}}^{3}$ respectively, from the southern Harz and the Unstrut-Saale area (Herrmann, 1988).

\subsection{Gas permeability at the test site in Seam Hessen}

Figure 2 displays the pressure trend over time for boreholes D1 to D5. Borehole D4 in the pillar was pressurized with Ar whereas the other boreholes were evacuated using a vacuum pump. A pressure loss in D4 and a pressure increase in the other holes can be observed. The increase in D5, at a distance of only $0.25 \mathrm{~m}$ to D4, is the strongest, whereas the pressure increase in D1 at a distance of $2.7 \mathrm{~m}$ is the slowest.

Using the pressure readings, the geometric conditions of the boreholes and the dynamic viscosity of Ar, the permeability of the salt rocks between the holes was calculated with the integrated form of Darcy's law for compressible fluids according to Eq. (2) (Müller-Lyda, 1999):

$k=\frac{2 \times Q \times \eta \times l \times P_{0}}{F \times\left(P_{1}^{2}-P_{2}^{2}\right)}$

where $k=$ permeability $\left(\mathrm{m}^{2}\right), P_{1}=$ pressure in the injection hole D4 (Pa), $Q=$ fluid flow $\left(\mathrm{m}^{3} \mathrm{~s}^{-1}\right), P_{2}=$ pressure in the observation holes $(\mathrm{Pa}), \eta=$ dynamic viscosity of $\operatorname{argon}(21 \times$ $10^{-6} \mathrm{~Pa}$ s) $P_{0}=$ pressure where $Q$ was measured $(\mathrm{Pa}), F=$
Table 1. Chemical composition of borehole gas D1, D2, D3, D5 as well as of bh-1.

\begin{tabular}{ll|rrrr|r}
\hline gas & & D1 & D2 & D3 & D5 & bh-1 \\
\hline $\mathrm{N}_{2}$ & vol. \% & 77.3 & 74.7 & 71.1 & 66.9 & 66.7 \\
$\mathrm{O}_{2}$ & vol. \% & 20.7 & 20.0 & 19.1 & 18.0 & 17.9 \\
$\mathrm{CH}_{4}$ & vol. \% & $<0.0005$ & 0.0095 & 0.012 & 0.022 & 1.19 \\
$\mathrm{CO}_{2}$ & vol. \% & 0.1045 & 0.3515 & 0.6985 & 1.32 & 11.8 \\
$\mathrm{H}_{2}$ & vol. \% & 0.0004 & 0.0013 & 0.0017 & 0.033 & 1.2 \\
$\mathrm{He}$ & vol. \% & 0.0004 & 0.0005 & 0.0005 & 0.0006 & 0.02 \\
$\mathrm{Ar}$ & vol. \% & 0.9515 & 3.96 & 8.27 & 12.9 & 0.8 \\
\hline
\end{tabular}

cross section area $\left(\mathrm{m}^{2}\right) l=$ distance between the bore holes (m).

The calculated permeability varies between $4 \times 10^{-17} \mathrm{~m}^{2}$ (between D4 and D5) and $4 \times 10^{-18} \mathrm{~m}^{2}$ (between D4 and D1). Natural undisturbed salt formations show permeabilities in the range of $10^{-21} \mathrm{~m}^{2}$ or lower (Miehe et al., 1993; Stormont, 1997). However, during the generation of subsurface cavities (boreholes, galleries, shafts), so-called relaxation areas with reduced mechanical stability and higher permeability by several orders of magnitudes are formed. The relaxation dimension includes about 2-3 $\mathrm{m}$ around the cavities (Miehe et al., 1993; Wieczorek and Zimmer, 1998). At the test site, it is likely that the rocks of the pillar are disturbed by the excavation and the drilling. This assumption is based on the observed rather large permeability of the pillar rocks, which is about 3-4 orders of magnitude higher than in undisturbed salt rocks. This leads to the conclusion that the migration of Ar gas most likely takes place along the micro-cracks that were produced during the mining process.

\subsection{Chemical and isotopic composition of borehole gas}

Table 1 shows the average chemical gas composition after six evacuation cycles of the sampling in boreholes D1, D2, D3 and D5. The gas sample of the isolated borehole bh-1 was taken before starting the Ar injection.

In addition to the injected $\mathrm{Ar}, \mathrm{O}_{2}$ was present in all samples, ranging between 17.9 vol. $\%$ and $20.7 \mathrm{vol} . \%$. Such high amounts of free molecular oxygen are unlikely to be found in salt rocks. Furthermore, the $\mathrm{O}_{2} / \mathrm{N}_{2}$ ratio corresponds to the air ratio and, therefore, we consider oxygen and nitrogen to be contaminants derived from the mine atmosphere.

The high Ar concentrations in the observation holes D1, D2, D3 and D5 result from the injection of Ar into hole D4. The Ar concentration in the boreholes is linearly correlated with the distance to the injection hole. D1, at a distance of $2.7 \mathrm{~m}$ to the injection hole shows the lowest Ar concentration with 9515 ppmv, whereas the Ar concentration in D5 at a distance of $0.25 \mathrm{~m}$ is the highest with $12.9 \mathrm{vol} . \%$.

Compared to their concentrations in the atmosphere, relatively high amounts of $\mathrm{CO}_{2}$ and $\mathrm{CH}_{4}$ as well as $\mathrm{H}_{2}$ were found in the borehole gas phase (Table 1), which are likely 


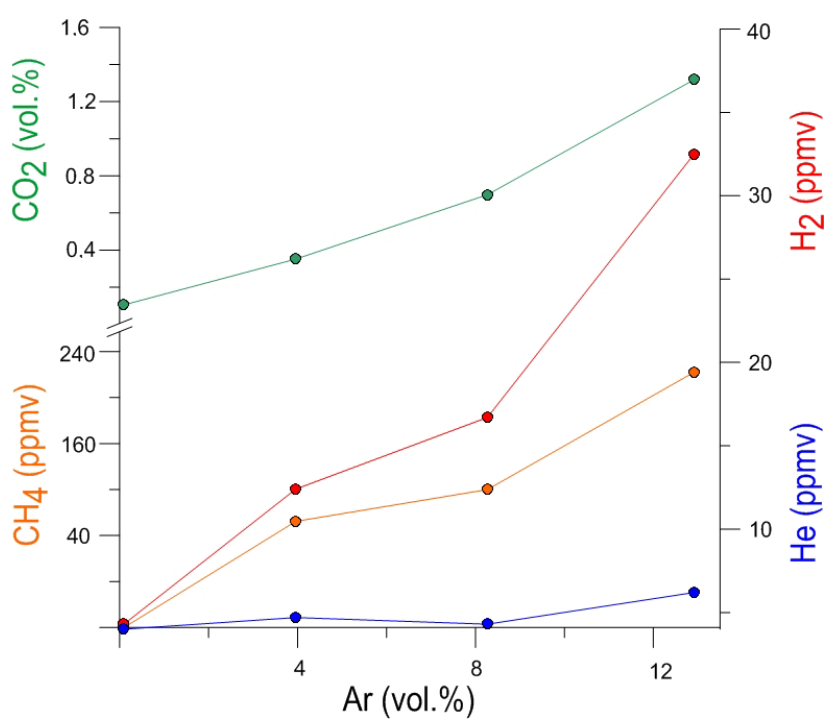

Figure 3. Average Ar-carrier gas concentration versus stripped geogenic gases in the boreholes D1, D2, D3 and D5.

to be of geogenic origin. In the D1 to D5 holes the concentration of $\mathrm{CO}_{2}$ ranges from $1045 \mathrm{ppmv}$ to $1.32 \mathrm{vol} . \%$, that of $\mathrm{CH}_{4}$ from 5 to $220 \mathrm{ppmv}$, that of $\mathrm{H}_{2}$ from 4 to $330 \mathrm{ppmv}$ and that of He from 4 to 6 ppmv. Generally, the lowest concentrations of these gases were found in D1 with the lowest Ar-carrier gas concentration and the highest in D5 with the highest Ar-carrier gas concentration. The geogenic $\mathrm{CO}_{2}$, $\mathrm{CH}_{4}, \mathrm{H}_{2}$ and $\mathrm{He}$ concentrations correlate directly to the $\mathrm{Ar}$ concentration in the borehole and suggest that argon strips geogenic gas that was already present in the rocks between the holes (Fig. 3).

The Ar concentration is about 10-times the geogenic gas concentration, meaning that one mole of Ar carrier gas stripped $0.1 \mathrm{~mol}$ of geogenic gas from the rocks. The volumetric ratios of all geogenic gases are relatively constant in all boreholes, pointing to a single source of these gases. The range of the air contamination-corrected and carrier gas freecalculated geogenic gas composition in the holes is:

$$
\begin{aligned}
& \mathrm{CO}_{2}=96.0-99.2 \text { vol. \%, } \\
& \mathrm{CH}_{4}=0.0005-2.6 \text { vol. \%, } \\
& \mathrm{H}_{2}=0.17-2.4 \text { vol. } \%, \\
& \mathrm{He}=0.07-0.44 \text { vol. } \%,
\end{aligned}
$$

A gas sample from bh-1, taken before the Ar injection, was used to perform noble gas and carbon isotope analyses. The composition of the gas phase is similar to that of the argon-stripped geogenic gases, dominated by $\mathrm{CO}_{2}$ with minor amounts of $\mathrm{CH}_{4}, \mathrm{H}_{2}$, He and $\mathrm{Ar}$ (Table 1).

The noble gas isotopes and the $\delta^{13} \mathrm{C}_{\text {of }} \mathrm{CO}_{2}$ and $\mathrm{CH}_{4}$ are shown in Table $2 .{ }^{20} \mathrm{Ne} /{ }^{22} \mathrm{Ne}$ and ${ }^{21} \mathrm{Ne} /{ }^{22} \mathrm{Ne}$ ratios are indistinguishable from air within the analytical uncertainties. The

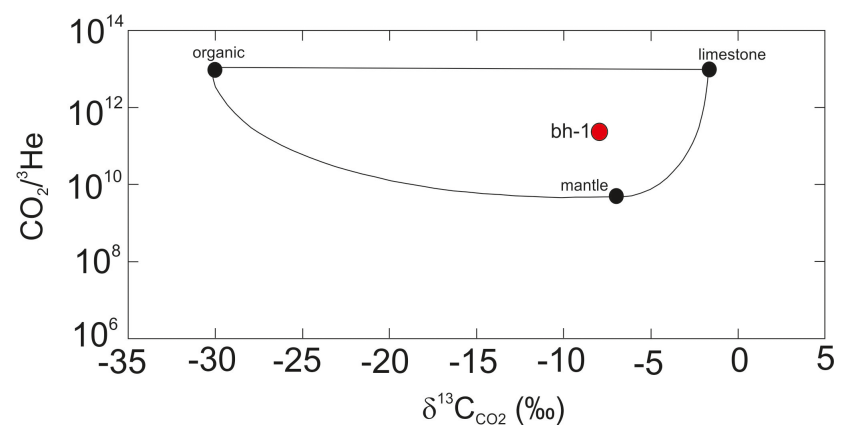

Figure 4. Genetic diagram $\mathrm{CO}_{2} /{ }^{3} \mathrm{He}$ versus $\delta^{13} \mathrm{C}_{\mathrm{CO}_{2}}$ (modified after Sano and Marty, 1995) for the borehole gas bh-1.

${ }^{40} \mathrm{Ar} /{ }^{36} \mathrm{Ar}$ ratio (326.6) found in the bh-1 pristine gas sample indicates a ${ }^{40} \mathrm{Ar}$ excess as compared to the ratio for air (298.56, Lee et al., 2006). ${ }^{40} \mathrm{Ar}$ is mainly produced by electron capture decay of ${ }^{40} \mathrm{~K}$ in the crust (e.g. Ozima and Podosek, 2002). The ${ }^{3} \mathrm{He} /{ }^{4} \mathrm{He}$ ratio is reported in Ra units, with $\mathrm{Ra}$ being the He isotopic ratio in the atmosphere and equal to $1.39 \times 10^{-6}$ (Ozima and Podosek, 2002). The measured value of $0.194 \mathrm{Ra}$ of the sample was corrected for atmospheric contamination based on the ${ }^{4} \mathrm{He} /{ }^{20} \mathrm{Ne}$ ratio according to Sano and Wakita (1985). The air-corrected ${ }^{3} \mathrm{He} /{ }^{4} \mathrm{He}$ ratio is $0.092 \mathrm{Ra}$ (Table 2) and indicates a small ${ }^{3} \mathrm{He}$ excess compared to the Earth's crust $(\sim 0.02 \mathrm{Ra})$ and, thus, a small contribution of a mantle component. Pure mantlederived gases are characterized by ${ }^{3} \mathrm{He} /{ }^{4} \mathrm{He}$ ratios of $\sim 6$ 8 Ra (Ozima and Podosek, 2002).

The $\delta^{13} \mathrm{C}_{\mathrm{CO}_{2}}$ values of bh- 1 and the Ar-stripped gas in D5 are $-7.8 \%$ and $-6.7 \%$, respectively. For comparison, the $\delta^{13} \mathrm{C}_{\mathrm{CO}_{2}}$ of air is $-8.9 \%$ (Graven et al., 2017), that of fossil fuel combustion varies between $-38 \%$ to $-24 \%$ (Pataki et al., 2003) and mantle $\mathrm{CO}_{2}$ has $\delta^{13} \mathrm{C}$ between -4 and $-8 \%$ o (Kyser, 1986). The $\mathrm{CO}_{2}$ isotopic composition of the potash mine gas matches with gases of a mantle source probably mixed with isotopically lighter e.g. organic or air components. This finding is supported by the genetic ${ }^{3} \mathrm{He}-\mathrm{CO}_{2}$ diagram, where the gas is indicated as a mixture of a mantle and some lighter components (Fig. 4). The mantle component can be provided by the Paleogene and Neogene Vogelsberg and the Rhön volcanism.

The generation of methane requires the involvement of organic matter, which is decomposed either by microbes or due to a temperature rise during the basin subsidence and/or locally by volcanic activity. The total carbon concentration in salt of the Zechstein in middle and northern Germany is in the range of $0.01 \%$ (Herrmann, 1988).

The $\delta^{13} \mathrm{C}$ of methane is $-22.2 \%$ and $-21.3 \%$ in samples bh-1 and D5, respectively. These relatively heavy isotopic compositions are typical values for thermogenic methane (Giggenbach, 1995; Whiticar, 1999). In the Werra formation (z1), hydrocarbons are often found in connection with basaltic dikes, fissures and $\mathrm{CO}_{2}$ (Herrmann, 1988). Under 
Table 2. Noble gas isotope ratios and $\delta^{13} \mathrm{C}$ of $\mathrm{CO}_{2}$ and $\mathrm{CH}_{4}$ of bh-1 pristine geogenic gas as well as the carbon isotope ratios determined in the Ar-stripped gas of D5 from the salt-pillar. Error limits are $2 \sigma$.

\begin{tabular}{llrr}
\hline Isotope & bh-1, pristine gas & Ar-stripped gas \\
\hline$\delta^{13} \mathrm{C}\left(\mathrm{CO}_{2}\right)$ & $\%$ VPDB & $-7.8 \pm 0.1$ & $-6.7 \pm 0.1$ \\
$\delta^{13} \mathrm{C}\left(\mathrm{CH}_{4}\right)$ & $\%$ VPDB & $-22.2 \pm 0.5$ & $-21.3 \pm 0.5$ \\
${ }^{3} \mathrm{He} /{ }^{4} \mathrm{He}$ & $R_{\mathrm{a}}$ (air-corrected) & $0.092 \pm 0.021$ & \\
${ }^{21} \mathrm{Ne} /{ }^{22} \mathrm{Ne}$ & & $0.02901 \pm 0.00030$ & \\
${ }^{20} \mathrm{Ne} /{ }^{22} \mathrm{Ne}$ & $9.7995 \pm 0.0097$ & \\
${ }^{40} \mathrm{Ar} /{ }^{36} \mathrm{Ar}$ & $326.6 \pm 1.5$ & \\
${ }^{40} \mathrm{He} /{ }^{20} \mathrm{Ne}$ & $2.83 \pm 0.2$ & \\
\hline
\end{tabular}

the assumption of the isotopic equilibration of carbon, the $\mathrm{CO}_{2}$ and $\mathrm{CH}_{4}$ isotopes reveal equilibration temperatures of $519^{\circ} \mathrm{C}$ and $513^{\circ} \mathrm{C}$ (Horita, 2001) for the bh-1 and D5 sample, respectively.

Methane may have been mobilised from organic material (lignite, organic carbon in the salt or clay layers) by the high temperatures in the vicinity of the basaltic dikes and then transported with the magmatic fluids $\left(\mathrm{CO}_{2}\right)$ in the salt formation.

\subsection{Model residence time of the gas}

Based on the concentration of the in situ-produced radiogenic isotope ${ }^{40} \mathrm{Ar}$, accumulated in the bore gas phase, it is possible to estimate the residence time of gas in the rocks. The production rate of ${ }^{40} \mathrm{Ar}\left(P_{40} \mathrm{Ar}=\mathrm{cm}_{\mathrm{STP}}^{3} \mathrm{~g}_{\text {rock }}^{-1} \mathrm{a}^{-1}\right)$ is proportional to the K-content in the rock. According to the decay parameters, $P_{40} \mathrm{Ar}$ is $3.885 \times 10^{-14}[\mathrm{~K}]$, where $[\mathrm{K}]$ is the concentration of the mother nuclide $\mathrm{K}$ in \% (Lippmann et al., 2003). Thus, for a concentration of potassium in the Seam Hessen of $10-11$ wt. \% (Struensee, 1987), the ${ }^{40} \mathrm{Ar}$ production should be $\sim 3.9 \times 10^{-13}$ to $4.3 \times 10^{-13} \mathrm{~cm}_{\text {STP }}^{3} \mathrm{~g}_{\text {rock }}^{-1} \mathrm{a}^{-1}$. The measured ${ }^{40} \mathrm{Ar}$ concentration in sample bh-1 was 0.8 vol. \%. Based on the ${ }^{40} \mathrm{Ar} /{ }^{36} \mathrm{Ar}$ ratio, the excess concentration of ${ }^{40} \mathrm{Ar}$ relative to air ratio is calculated to be $8.6 \%$, which corresponds to $0.067 \mathrm{vol} \%$ in bh- 1 . We determined the total gas amount in the potassium-bearing salt, to be $9 \times 10^{-3} \mathrm{~cm}_{\mathrm{STP}}^{3} \mathrm{~g}_{\text {rock }}^{-1}$. The ${ }^{40} \mathrm{Ar}$ excess is, therefore, $6 \times 10^{-6} \mathrm{~cm}_{\mathrm{STP}}^{3} \mathrm{~g}_{\text {rock }}^{-1}$, indicating a residence age of about $15-16 \mathrm{Ma}$. With all the uncertainties of this calculation, this model residence time coincides with the end of the basaltic volcanism in the area. It appears plausible that the $\mathrm{CO}_{2}$ and $\mathrm{CH}_{4}$ gases in the salt rocks are related to the Neogene volcanic activity, where the $\mathrm{CO}_{2}$ originated directly from the magmatic source and the $\mathrm{CH}_{4}$ was formed from organic material in the vicinity of the basaltic dikes. The gas was mobilised and transported into the evaporites of the WerraFormation (z1), where it was bound at the grain boundaries.

\section{Conclusions}

In this study, gases of the Seam Hessen (z1KHe) potash layer from the Werra-Fulda basin were investigated. The aim was to characterise the gas composition, to better understand how the gases are trapped in the salt and to investigate their origin.

We conclude that the permeability of the salt rocks in the testing area is significantly increased through disturbance by the excavation process and that micro-cracks are produced which dominate the gas flux in the rocks. The injected Ar flows along these micro-cracks and strips geogenic gases from the mineral boundaries. The liberated geogenic gas is dominated by $\mathrm{CO}_{2}$, accompanied by minor amounts of $\mathrm{CH}_{4}$ and $\mathrm{H}_{2}$. The ${ }^{3} \mathrm{He} /{ }^{4} \mathrm{He}$ ratio indicates a small contribution of mantle gas. The carbon isotopic composition of $\mathrm{CO}_{2}$ indicates a magmatic source, whereas $\delta^{13} \mathrm{C}_{\text {of }} \mathrm{CH}_{4}$ is typical for a thermogenic gas. The isotopic equilibration temperature of $\mathrm{CO}_{2}$ and $\mathrm{CH}_{4}$ is $513-519^{\circ} \mathrm{C}$. Such a high temperature may have occurred in the vicinity of basaltic dikes cutting through the evaporites. It appears plausible that the $\mathrm{CO}_{2}$ and $\mathrm{CH}_{4}$ gases in the salt rocks are related to the Neogene volcanic activity, where the $\mathrm{CO}_{2}$ originated directly from the magmatic source and the $\mathrm{CH}_{4}$ was formed from organic material in the vicinity of the basaltic dikes and mobilized and transported in the evaporites, where it is bound and fixed at the grain boundaries. Model residence time calculations of the gas reveal ages between about 15 and $16 \mathrm{Ma}$, which are in accordance with the end of the volcanic activity in the area.

Data availability. The data are accessible in the data repository of the GFZ at: https://doi.org/10.5880/GFZ.3.1.2020.004 (Zimmer et al., 2020).

Author contributions. All authors contributed to ideas, text and figures. MZ and BS setup the equipment and developed and performed the experiments underground. They downloaded the data and collected samples and analysed their chemical composition in the laboratory. AZ was responsible for all logistical needs in the mine and supervised the drilling activities underground. SN performed the noble gas isotopic analyses and $\mathrm{AVH}$ the ${ }^{13} \mathrm{C} /{ }^{12} \mathrm{C}$ analyses of $\mathrm{CH}_{4}$ and $\mathrm{CO}_{2}$. 
Competing interests. The authors declare that they have no conflict of interest.

Special issue statement. This article is part of the special issue "European Geosciences Union General Assembly 2020, EGU Division Energy, Resources \& Environment (ERE)"'. It is a result of the EGU General Assembly 2020, 4-8 May 2020.

Acknowledgements. We thank the staff of the Neuhof-Ellers potash mine for their help and great support with sampling and logistics underground. We also highly appreciate the proofreading of the manuscript by Mary T. Lavin-Zimmer. We gratefully acknowledge the financial support of the BMBF within the framework program Geo:N-geoscience for sustainability. This study is part of the project ProSalz (03G0873B). The manuscript highly benefited from the reviews of Johannes Barth and an anonymous reviewer.

Financial support. This research has been supported by the BMBF (project ProSalz (grant no. 03G0873B)).

The article processing charges for this open-access publication were covered by a Research Centre of the Helmholtz Association.

Review statement. This paper was edited by Johannes Miocic and reviewed by Johannes Barth and one anonymous referee.

\section{References}

Abratis, M., Mädler, J., Hautmann, S., Leyk, H.-J., Meyer, R., Lippolt, H. J., and Viereck-Götte, L.: Two distinct Miocene age ranges of basaltic rocks from the Rhön and Heldburg areas (Germany) based on ${ }^{40} \mathrm{Ar} /{ }^{39} \mathrm{Ar}$ step heating data, Chemie der Erde, 67, 133-150, 2007.

Dietz, C.: Die Salzlagerstätte des Werra-Kaligebietes, Archiv für Lagerstättenforschung Heft 40, Herausgegeben von der Preußischen Geologischen Landesanstalt, Berlin, p. 79, 1928.

Giggenbach, W. F.: Variations in the chemical and isotopic composition of fluids discharged from the Taupo Volcanic Zone, New Zealand J. Volcanol. Geotherm. Res., 68, 89-116, 1995.

Graven, H., Allison, C. E., Etheridge, D. M., Hammer, S., Keeling, R. F., Levin, I., Meijer, H. A. J., Rubino, M., Tans, P. P., Trudinger, C. M., Vaughn, B. H., and White, J. W. C.: Compiled records of carbon isotopes in atmospheric $\mathrm{CO}_{2}$ for historical simulations in CMIP6, Geosci. Model Dev., 10, 4405-4417, https://doi.org/10.5194/gmd-10-4405-2017, 2017.

Herrmann, A. G.: Gase in marinen Evaporiten, PhysikalischTechnische Bundesanstalt Braunschweig und Berlin, 2/88, Presse- und Öffentlichkeitsarbeit für die Abteilung SE, Braunschweig, Redaktion Dr. Eckart Viehl, Fischer Druck + Verlag, Wolfenbüttel, 33 pp., 1988.

Hofrichter, E.: Zur Frage der Porosität und Permeabilität von Salzgesteinen, Erdoel-Erdgas-Zeitschrift, 92, 77-80, 1976.
Horita, J.: Carbon isotope exchange in the system $\mathrm{CO}_{2}-\mathrm{CH}_{4}$ at elevated temperatures, Geochim. Cosmochim. Ac., 65, 1907-1919, 2001.

Junghans, R.: Der schwere $\mathrm{CO}_{2}$-Ausbruch auf der Schachtanlage Menzengraben des VEB Kaliwerk Heiligenroda am 7.7.1953, seine Ursachen und Folgen, Bergbautechnik 3. Jg. Heft, 9, 457462, 1955.

Knipping, B.: Basalt Intrusions in Evaporites, Lecture Notes in Earth Sciences 24, edited by: Bhattacharji, S., Friedman, G. M., Neugebauer, H. J., and Seilacher, A., Springer-Verlag Berlin Heidelberg New York London Paris Tokyo Hong Kong, 133 pp., 1989.

Kyser, T. K.: Stable isotope variations in the mantle, in: Stable isotopes in high temperature geological processes. Reviews in Mineralogy Volume 16, Mineralogical Society of America, edited by: Valley, J. W., Taylor Jr., H. P., and O’Neil, J. R., BookCrafters, Inc., Chelsea, Michigan, 141-164, 1986.

Lee, J.-Y., Marti, K., Severinghaus J. P., Kawamura, K., Yoo, H.S., Lee, J. B., and Kim, J. S.: A redetermination of the isotopic abundances of atmospheric Ar, Geochim. Cosmochim. Ac., 70, 4507-4512, 2006.

Lippmann, J., Stute, M., Torgersen, T., Moser, D. P., Hall, J. A., Lin, L., Borcsik, M., Bellamy, R. E. S., and Onstott, T. C.: Dating ultra-deep mine waters with noble gases and ${ }^{36} \mathrm{Cl}$, Witwatersrand Basin, South Africa, Geochim. Cosmochim. Ac., 67, 4597-4619, 2003.

Miehe, R., Harborth, B., Klarr, K., and Ostrowski, L.: Permeabilitätsbestimmungen im Staßfurt-Steinsalz in Abhängigkeit von einer Streckenauffahrung. Kali und Steinsalz Bd. 11 Heft 5/6, 175-184, 1993.

Müller, W.: Über das Auftreten von Kohlensäure im WerraKaligebiet, Freiberger Forschungshefte, A(101), 1-100, 1958.

Müller-Lyda, I.: Permeabilität von aufgelockertem Steinsalz, GRS - Bericht 151, 77 pp., 1999.

Nesbor, H.-D.: Das Vulkangebiet Vogelsberg, Geologisches Jahrbuch Hessen 139, 5-41, 2018.

Ozima, M. and Podosek, F. A.: Noble Gas Geochemistry, 2nd ed, Cambridge University Press, Cambridge, New York, Melbourne, 2002.

Pataki, D. E., Ehleringer, J. R., Flanagan, L. B., Yakir, D., Bowling, D. R., Still, C. J., Buchmann, N., Kaplan, J. O., and Berry, J. A.: The application and interpretation of Keeling plots in terrestrial carbon cycle research, Global Biogeochem. Cy., 17, 1022, https://doi.org/10.1029/2001GB001850, 2003.

Sano, Y. and Marty, B.: Origin of carbon in fumarolic gas from island arcs, Chem. Geol., 119, 265-274, 1995.

Sano, Y. and Wakita, H.: Geographical distribution of ${ }^{3} \mathrm{He} /{ }^{4} \mathrm{He}$ in Japan: implications for arc tectonics and incipient magmatism, J. Geophys. Res., 90, 8729-8741, 1985.

Stormont, J. C.: Conduct and interpretation of gas permeability measured in rock salt, Int. J. Rock Mech. Min. Sci., 34, 303, https://doi.org/10.1016/S1365-1609(97)00250-5, 1997.

Struensee, G. v.: Befahrung des Werra-Salinars mit den Kaliflözen Hessen $(\mathrm{K} 1 \mathrm{H})$ und Thüringen $(\mathrm{K} 1 \mathrm{Th})$ sowie des miozänen Vulkanismus im Bereich der 1. und 2. Sohle, Exkursion A, Exkursionsführer 1987 Kassel, Hannover, International Symposium Zechstein, edited by: Kulick, J., Wiesbaden, 37-45, 1987. 
Whiticar, M. J.: Carbon and hydrogen isotope systematics of bacterial formation and oxidation of methane, Chem. Geol., 161, 291314, 1999.

Wieczorek, K. and Zimmer, U.: Untersuchungen zur Auflockerungszone um Hohlräume im Salzgebirge, Abschlußbericht, Gesellschaft für Anlagen- und Reaktorsicherheit mbH, GRS-A-2651, Braunschweig, 1998.
Zimmer, M., Strauch, B., Zirkler, A., Niedermann, S., and Vieth-Hillebrand, A.: Chemical and Isotopic Composition of Gas in Salt Beds of a Potash Mine, GFZ Data Services, https://doi.org/10.5880/GFZ.3.1.2020.004, 2020. 